Review

\title{
The Pathogenesis of Rift Valley Fever
}

\author{
Tetsuro Ikegami ${ }^{1,3,4, *}$ and Shinji Makino ${ }^{2,3,4}$
}

1 Department of Pathology, The University of Texas Medical Branch, 301 University Blvd. Galveston, TX 77555, USA

2 Department of Microbiology and Immunology, The University of Texas Medical Branch, 301 University Blvd. Galveston, TX 77555, USA; E-Mail: shmakino@utmb.edu

3 The Sealy Center for Vaccine Development, The University of Texas Medical Branch, 301 University Blvd. Galveston, TX 77555, USA

4 The Center for Biodefense and Emerging Infectious Diseases, The University of Texas Medical Branch, 301 University Blvd. Galveston, TX 77555, USA

* Author to whom correspondence should be addressed; E-Mail: teikegam@utmb.edu; Tel.: +1-409-772-2563; Fax: +1-409-747-1763.

Received: 31 March 2011; in revised form: 26 April 2011 / Accepted: 2 May 2011 /

Published: 6 May 2011

\begin{abstract}
Rift Valley fever (RVF) is an emerging zoonotic disease distributed in sub-Saharan African countries and the Arabian Peninsula. The disease is caused by the Rift Valley fever virus (RVFV) of the family Bunyaviridae and the genus Phlebovirus. The virus is transmitted by mosquitoes, and virus replication in domestic ruminant results in high rates of mortality and abortion. RVFV infection in humans usually causes a self-limiting, acute and febrile illness; however, a small number of cases progress to neurological disorders, partial or complete blindness, hemorrhagic fever, or thrombosis. This review describes the pathology of RVF in human patients and several animal models, and summarizes the role of viral virulence factors and host factors that affect RVFV pathogenesis.
\end{abstract}

Keywords: Rift Valley fever virus; pathogenesis; hemorrhagic fever; encephalitis; blindness 


\section{Introduction}

Rift Valley fever (RVF), a mosquito-borne zoonotic disease among humans and ruminants, is caused by Rift Valley fever virus (RVFV) belonging to family Bunyaviridae, genus Phlebovirus [1,2]. RVF is endemic to sub-Saharan African countries and has caused major outbreaks in several countries including Kenya, Tanzania, Somalia, South Africa, Madagascar, Egypt, Sudan, Mauritania, Senegal, Saudi Arabia, and Yemen [3]. Pregnant ruminants infected with RVFV typically are subject to highrate abortions, fetal malformation, and subclinical-to-fatal febrile illness, while newborn lambs usually die by acute hepatitis [4-6]. RVFV infection in humans primarily causes a self-limiting febrile illness; however, some patients develop hemorrhagic fever, neurological disorders, or blindness after the febrile period [5,7,8]. In endemic area, floodwater Aedes mosquitoes, such as Ae.mcintoshi or Ae.vexans, serve as vectors, and the virus could be transmitted into offspring transovarially $[9,10]$. Heavy rainfall or flooding of river banks due to construction of dams increases the number of permanent fresh water species of mosquitoes such as Culex pipens, which play a role in amplifying RVFV among mosquitoes, ruminants and humans [10-15]. An outbreak of RVF in developed countries, e.g., the U.S. or Europe, could force a curtailing of livestock movement to prevent RVFV spread, causing massive economic loss, and a substantial degree of panic in our society, because the body fluids of infected animals contain infectious RVFV [16,17], and mosquitoes such as Culex spp. Aedes spp. or Anopheles spp. might further spread RVFV into other mosquitoes, humans and animals [18-20]. Effective vaccines and antiviral drugs are necessary for the containment of outbreaks and treatment of RVF patients, respectively. However, neither safe and effective vaccines nor efficient treatment is available. A correct understanding of RVF pathogenesis is essential for the development of effective vaccines and antiviral drugs against RVF. In this review, we will describe clinical and pathological findings of RVF in humans and animals and discuss viral and host factors that affect RVF pathogenesis.

\section{Pathogenesis of RVF in Humans and Animals}

\subsection{Human}

Most RVF patients suffer from a self-limiting, febrile illness. However, some patients develop neurological disorders, vision loss, hemorrhagic fever, or thrombosis as shown in Figure 1.

\subsubsection{Self-Limiting Febrile Illness}

In the 1930s-40s, many RVFV laboratory infections occurred due to a lack of appropriate biosafety procedures [21-25]. However, the patients in most of these and later outbreaks suffered from self-limiting and nonfatal illness [4,6,22,23,25-28]. Typically, the incubation period for RVF is 4 to 6 days. Symptoms start abruptly with severe chills, malaise, dizziness, weakness, severe headache, nausea and/or sensation of fullness over the liver region [6,22,23]. These symptoms are followed by an elevated body temperature $\left(38.8^{\circ} \mathrm{C}\right.$ to $\left.39.5^{\circ} \mathrm{C}\right)$; decreased blood pressure; pain in the back, shoulders, neck or legs; rigor; shivering; flushed face; red eye with sore; constipation; insomnia and/or photophobia. Occasionally, other symptoms are seen which include epistaxis, abdominal pain, lack of 
gustatory discrimination, vomiting and/or diarrhea $[4,6,22,25,26,28]$. Some lessening of symptoms can be observed on the 3rd day, and the body temperature often decreases to a normal level by the 4th day after the onset of symptoms. However, within 1 to 3 days after the recovery of body temperature, some patients again experience a temporal recurrence of high fever with a severe headache for a few days $[6,25,26]$. Moreover, patients may have a long-lasting high fever for as much as 10 days [6]. After body temperature becomes normal, some patients may develop a massive coronary thrombosis [26], persistent aching of legs for two weeks [4,22], or persistent abdominal discomfort for weeks [4]. The palpable enlargement of the liver and spleen is not common. In the convalescence phase, patients often experience weakness, malaise, a tendency to sweat, frequent headaches, pain on motion of the eye, and a sense of imbalance. Virus has been demonstrated in the blood during the febrile period (3-4 days), whereas neutralizing antibody also starts appearing around the 4th day of the onset of symptoms $[6,22,24,25,27]$.

Figure 1. The pathological forms of Rift Valley fever in humans.

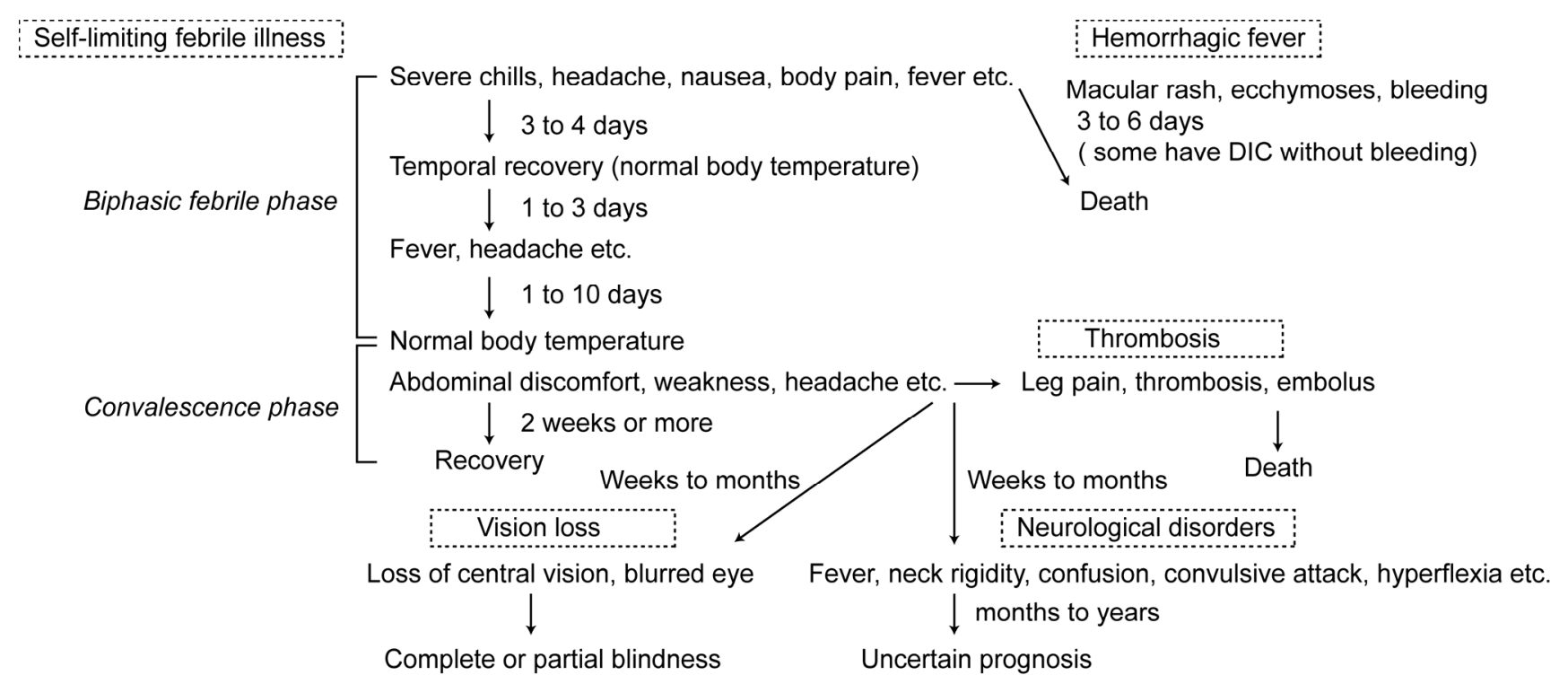

\subsubsection{Neurological Disorders}

Maar et al. described a case of encephalitis in a RVF patient [29]. The patient exhibited symptoms of sudden fever, rigor, and retro-orbital headache for two days. He had fever again at the 22nd day after the onset of illness and experienced neck rigidity lasting for five days from the 25th day. Subsequently, he was sometimes confused and otherwise mentally affected, and experienced temporal vision loss without detectable retinopathy. He also exhibited convulsive attacks, hyperflexia and fever until the 50th day. His serum contained anti-RVFV hemagglutination (HAI) antibodies of 1:160 at the 25th day and 1:640 at the 40th day, while his cerebrospinal fluid (CSF) contained 1:2 of HAI antibody at the 28th day and 1:64 at the 50th day. The CSF also contained an increased number of white blood cells consisting mainly of lymphocytes at the 28th day, indicative of the possible occurrence of viral meningitis or meningoencephalitis. The patient recovered after treatment with amantadine, rifampicin, and dexamethasone for two weeks, although the effect of therapy could not be evaluated precisely. 
Another case with encephalitis and retinitis was described by Alrajhi et al. [30]. The patient had a fever, ataxic gait, and bilateral retinal hemorrhage. She could not count fingers, and the CSF contained many leukocytes, including lymphocytes. Her consciousness level was decreased. She was discharged on day 30 of the illness to her home, at which time she was awake, blind, quadreparetic, and incontinent. Moreover, her neurologic conditions did not improve for the next year.

An additional report described a patient who had persistent hemiparesis for four months after the onset of illness [31], and another paper reported 12 RVF patients, who developed neurological signs and symptoms, including meningeal irritation, confusion, stupor and coma, hypersalivation, teeth-grinding, visual hallucinations, locked-in syndrome, and choreiform movement of upper limbs [32]; in these patients, the histopathological lesions in brains were characterized by focal necroses associated with an infiltration of round cells, mostly lymphocytes and macrophages, and perivascular cuffing [32].

\subsubsection{Vision Loss}

Some patients suffer from maculopathy or retinopathy. Patients noticed the loss of central vision or blurred eye occurring at various times after infection; e.g., from immediately after the disease onset to several weeks or months later. One or both eyes could be affected [33-35], and the affected eyes had macular edema with exudates containing a white mass covering the macular area with or without retinal hemorrhage, vasculitis, infarction or vitreous haze [34-39]. In addition, retinal detachment [35,36], uveitis [38,39], or arterial occlusion [35,36,39-41] was reported in some patients. In many cases, a complete recovery of vision does not occur, and chorioretinal scarring can remain in macular and paramacular areas, in spite of the resorption of exudates [34,35,37-41], while some patients show partial improvement in vision after several months of RVFV infection $[34,36,38,40]$.

\subsubsection{Hemorrhagic Fever}

Fatal RVF cases often involve hemorrhagic manifestations but the time to death varies among cases [42-44]. Most typically, the illness starts suddenly, and the patients experience fever, rigor, nausea, vomiting, headache, injected conjunctives, drowsiness, and/or body pains. The patients may also have such symptoms as macular rash over the entire trunk, ecchymoses on the arms, limbs, and/or eyelids, bleeding from the gums and/or gastrointestinal mucosal membrane, low blood pressure, hematemesis, melena, diarrhea, throat pain, pneumonitis, jaundice, and/or hepatosplenomegaly [42,43]. Typically, elevation of alanine aminotransferase (ALT), aspartate aminotransferase (AST), lactate dehydrogenase (LDH), and reduction of platelet count and hemoglobin are seen in these patients $[42,45]$. In many cases, death occurs in 3 to 6 days after patients become symptomatic; however, in some cases, death occurs in 12 to 17 days after the onset of symptoms. Postmortem examination shows diffuse necrosis of hepatocytes which more greatly affect the centrilobular area than the portal area, which may indicate association with acute hepatic injury in this type of pathogenesis $[42,44]$. It should be noted that some patients who do not exhibit jaundice or hemorrhage, die from renal failure or disseminated intravascular coagulation (DIC) accompanied by an elevation of ALT, AST, LDH or D-Dimer, or a decrease in platelet count [46,47]. A group of RVF patients who died from typical hemorrhagic fever also had encephalitis in addition to hepatic and gastro-intestinal necroses [32], which demonstrates the neuroinvasiveness of RVFV in hemorrhagic patients. 


\subsubsection{Thrombosis}

Another type of fatal case of RVFV infection was described by Schwentker et al. [21]. They reported that the temperature of the patient fell to normal on the 4th day after the onset of symptoms, whereas two papular areas of several centimeter in diameter were found on the patient's thigh and leg on the 5th day and remained until day 8. After temporal recovery by the 12 th day, the patient experienced phlebitis of the popliteal vein, which was followed by infarcts in the lungs on the 20th, 26th and 34th days at multiple locations; these eventually caused a fatal embolus in the pulmonary vessels on the 45th day of illness. The liver of the patient was normal, did not contain infectious RVFV, and no typical RVF lesions were confirmed at the postmortem histopathological examination. However, there was a large thrombus in the inferior vena cava, a part of which might have detached and caused an embolus in the pulmonary artery. The neutralizing antibody showed up on the 6th day of illness, and its titer increased toward the 12th day.

\subsubsection{Possible Vertical Infection}

In a retrospective study in Egypt, no increases in the total number of abortions were seen during an RVF outbreak, and the serological conversion rate of aborted women before and after outbreak was $31.1 \%$ and $27.5 \%$, respectively [48]. A report describing a potential vertical infection of RVFV concerned a pregnant woman, who experienced fever, headache, dizziness and generalized muscle ache four days before delivery during the RVF outbreak in Saudi Arabia in 2000 and developed IgG specific to RVFV [49]. Her newborn baby presented with an anti-RVFV IgM antibody, as well as ALT/AST elevation, jaundice, extension of the activated partial thromboplastin time (APTT: test for the deficiency of intrinsic pathway factors) and the prothrombin time (PT: test for the deficiency of extrinsic pathway factors), and died on the 6th day after birth [49]. Although it is unknown whether the newborn baby died from RVF, it is possible that a vertical transmission in utero might have occurred in this case.

The clinical symptoms of RVF vary among patients. The determinant of host susceptibility to induce hemorrhagic fever in humans has not been characterized. It is also unknown how RVFV causes diseases such as neurological disorders, vision loss or thrombosis in the presence of protective antibodies. Several animal models have been used to understand the pathology of RVF, and the advantages and disadvantages of different animal models are summarized in Table 1. We discuss the pathological findings in various different animal models in the next chapter.

\subsection{Mouse}

Mice are one of the most susceptible animal species to RVFV infection [6,8], and RVF pathology in infected mice mimics the pathological findings in newborn lambs [6]. Most of the mice infected with wild-type (wt) RVFV ZH548 or ZH501 strains die in 3 to 5 days [50-52], whereas they die faster by infection with other wt isolates [6,53]. Infected mice show ruffed fur with decreased activity in 2 to 3 days, and then become more lethargic while lying with their back legs wide apart [6,52]. The symptom is often followed by death within one hour [6]. Occasionally, mice survive this stage, yet have hind limb paralysis at days 8-9 post infection (p.i.) and die from encephalitis [52]. The rectal temperature of 
infected mice is often normal or decreased to below normal [54]. Also, the clotting time of blood derived from RVFV-infected mice is significantly extended, and it clots normally by mixing with normal sera, a finding that may indicate the shortage of coagulation factors is important for the extension of clotting time [54].

Table 1. Advantages and disadvantages of animal models for Rift Valley fever.

\begin{tabular}{|c|c|c|}
\hline Model & Advantages & Disadvantages \\
\hline Mouse & $\begin{array}{l}\text { - Highly susceptible to RVFV } \\
\text { - Infected mice usually die in } 2 \text { weeks, and are } \\
\text { suitable for RVFV challenge study } \\
\text { - Acute hepatitis and lethal meningoencephalitis at } \\
\text { late stage } \\
\text { - Cost-effective }\end{array}$ & $\begin{array}{l}\text { - No hemorrhagic fever } \\
\text { - No ocular diseases }\end{array}$ \\
\hline Rat & $\begin{array}{l}\text { - Varied susceptibility among inbred strains } \\
\text { - Suitable for studying host genes responsible for } \\
\text { RVFV-resistant phenotype } \\
\text { - Similar pathological changes to those in mice } \\
\text { - A report suggests the presence of uveitis after } \\
\text { aerosol challenge } \\
\text { - Cost-effective }\end{array}$ & $\begin{array}{l}\text { - The inbred strains of same name } \\
\text { derived from different breeding } \\
\text { colonies have different susceptibility } \\
\text { to RVFV. } \\
\text { - Age-dependent difference in } \\
\text { susceptibility }\end{array}$ \\
\hline Hamster & $\begin{array}{l}\text { - Highly susceptible to RVFV } \\
\text { - Similar pathological change to those seen in mice } \\
\text { - Often used for experimental RVFV transmission by } \\
\text { mosquitoes }\end{array}$ & $\begin{array}{l}\text { - No hemorrhagic fever } \\
\text { - No ocular diseases } \\
\text { - Limited research resources }\end{array}$ \\
\hline Gerbil & $\begin{array}{l}\text { - Encephalitis with minimum liver diseases } \\
\text { - Useful for studying neuroinvasiveness }\end{array}$ & $\begin{array}{l}\text { - No significant diseases except for } \\
\text { Encephalitis } \\
\text { - Age-dependent difference in } \\
\text { susceptibility } \\
\text { - Limited research resources }\end{array}$ \\
\hline $\begin{array}{l}\text { Rhesus } \\
\text { monkey }\end{array}$ & $\begin{array}{l}\text { - Lethal hemorrhagic fever } \\
\text { - Similar susceptibility to humans } \\
\text { - Important for testing the safety of vaccines or } \\
\text { antivirals before clinical trial }\end{array}$ & $\begin{array}{l}\text { - No ocular diseases reported } \\
\text { - Less than } 20 \% \text { develop hemorrhagic } \\
\text { fever } \\
\text { - Requirement of ABSL4 or BSL3+ } \\
\text { space to keep monkeys } \\
\text { - Expensive }\end{array}$ \\
\hline $\begin{array}{l}\text { Adult } \\
\text { sheep, } \\
\text { ewe }\end{array}$ & $\begin{array}{l}\text { - A report suggests the occurrence of hemorrhagic } \\
\text { fever and edema of corneal and choroidal edema } \\
\text { with inflammation } \\
\text { - High rate of abortion and fetal malformation } \\
\text { - Suitable for veterinary vaccine study }\end{array}$ & $\begin{array}{l}\text { - Susceptibility varies among different } \\
\text { breeds } \\
\text { - Requirement of ABSL4 or BSL3+ for } \\
\text { large animals } \\
\text { - Limited research resources } \\
\text { - Expensive }\end{array}$ \\
\hline Lamb & $\begin{array}{l}\text { - Highly susceptible to RVFV } \\
\text { - Lethal acute hepatitis } \\
\text { - Important to evaluate the effect of collostrum from } \\
\text { vaccinated ewes }\end{array}$ & $\begin{array}{l}\text { - Neurovirulence is not prominent } \\
\text { - No hemorrhagic fever } \\
\text { - No ocular diseases } \\
\text { - Requirement of ABSL4 or BSL3+ for } \\
\text { large animals } \\
\text { - Limited research resources }\end{array}$ \\
\hline
\end{tabular}

The liver is the major target organ of RVFV, while the enlargement of liver is not common [6,52]. Liver lesions are characterized by fulminant hepatitis, with coagulative necroses leaving the portal space intact $[50,52,55,56]$. Depletion of glycogen in hepatocytes is also common at an early stage [6,51,55]. Infected hepatocytes in mice contain eosinophilic intranuclear inclusion bodies [6,52], 
which are not reactive to the Feulgen reaction, a nucleic acid stain [57]. The intranuclear inclusion bodies in RVFV-infected cultured cells were visualized by an indirect immunofluorescent assay with antisera against RVFV and found to have a filamentary shape [58]. Inclusion bodies are formed by the NSs protein [59], a viral nonstructural protein, and the 10-to-17 amino acids at the carboxyl terminus of NSs are responsible for the formation of the filamentous structures via self-association [60]. Viral antigens start accumulating in hepatocytes at day 2, and their abundance increases extensively at day 3 p.i. [52]. The infected hepatocytes are stained by using a terminal deoxynucleotidyl transferase dUTP nick end labeling (TUNEL) assay, indicating that RVFV replication induces apoptosis in hepatocytes [52]. Mice that survived the early hepatitis phase often are able to regenerate hepatocytes [52,61]. Although swollen endothelial cells can be observed in the liver [6], antigens are not easily detectable in endothelial cells or Kuppfer cells, which indicate that these cells are not the primary targets of RVFV [52,55].

In addition to hepatocytes, viral antigens have been detected in, odontogenic and gingival epithelium; lipocytes; pituicytes; olfactory neurons and multiple types of neurons in the brain; mononuclear phagocytes; cardiac myofibers; and in perineural, periosteal, adrenocortical, endosteal, perivascular, bone marrow stromal, fibroblastic reticular, and vascular smooth muscle cells, as well as in cells morphologically consistent with dendritic, pancreatic islet, and adrenal medullary cells; however, no viral antigens were reported in any ocular structure, including the retina [52]. Apoptosis of lymphocytes were found in the thymus, spleen, lymph nodes and mucosa-associated lymphoid tissues [52]. Congestion and hemorrhage are common to the liver, spleen, lymph nodes, large intestine, kidneys and brain [6,52], but are uncommon in the jejunum [54]. In some mice that survived acute viral hepatitis, a sharp decrease in viral antigens occurred at 8 days p.i., and no virus could be detected in the sera, liver, lung, pancreas, large intestine and ovaries [52]. In the late stage of infection, however, lethal meningoencephalitis characterized by neuronal necrosis, microhemorrhages, and perivascular cuffs occurs in mice that survived the acute hepatitis [52].

\subsection{Rat}

The susceptibility of rats to RVFV differs among rat strains [62]. Peters et al. demonstrated that 10-to-15-week-old inbred rats from U.S. breeders exhibited three different responses to subcutaneous (s.c.) RVFV inoculation [63,64]. Wistar-Furth (WF) and Brown Norway strains were highly susceptible to RVFV and died within four days p.i. by liver necrosis, while the Fisher 344, Buffalo, DA and Lewis strains were largely resistant to RVFV infection [64]. ACI and Maax strains proved to be moderately susceptible and showed ascending paralysis; lesions were mainly in the brain and spinal cord and characterized as mild-to-severe necrotizing encephalitis and encephalomyelitis with focal necrosis with neutrophilic infiltrate and perivascular cuffing primarily with lymphocytes. In the ACI and Maax strains, viruses were undetectable in the liver and blood, whereas 5-to-6 log pfu/g of viruses could be detected from brain tissue, even in the presence of neutralizing antibody in the serum. The intracranial injection of RVFV uniformly caused encephalitis in these rats, including the resistant Lewis strain. The immunosuppression of the resistant Lewis rats by treating animals with cyclophosphamide 1 day prior to s.c. RVFV infection resulted in death at around 5-to-7 days p.i. with increased viral titers in the serum, liver, spleen, brain, kidneys and adrenal gland, although the virus 
titers in these organs in the Lewis rat were still lower than those in the corresponding organs of the WF strain [65]. These data suggest that the Lewis rat encodes a gene(s) important for the resistant phenotype. Interestingly, WF (WF/mol) and Lewis rats (Lewis/mol) obtained from a European breeding colony are resistant and susceptible to RVFV, respectively; hence, these rats showed the opposite susceptibilities to RVFV infection to those of the same strains from U.S. breeders. Furthermore, both WF and Lewis rats obtained from another European breeder were resistant to RVFV infection; taken together, these findings indicate the possible genetic variability of inbred rats among different breeders [66]. Cross-breeding experiments culminated in findings that indicated the resistance of $\mathrm{WF} / \mathrm{mol}$ rat was segregated as a single Mendelian dominant locus [66]. Findlay et al. also showed that the albino rat of the Glaxo strain had an age-dependent susceptibility to RVFV via the i.p. route infection [62]; rats younger than 15 days died in 2 to 4 days with extensive liver necrosis, whereas 26-day-old rats survived RVFV infection [62].

\subsection{Hamster}

The Syrian hamster is one of the most susceptible rodents to RVFV. Death occurs in 2 to 3 days p.i. after intraperitoneal inoculation with massive liver necrosis [6,67]. The pathological changes are similar to those seen in mice [6]. Administration of low titers of neutralizing antibodies protects hamsters from fatal liver necrosis, yet infected hamsters die from encephalitis by day 11 [67].

\subsection{Gerbil}

The gerbil, Meriones unguiculatus, represents a unique RVFV animal model, which produces fatal encephalitis with minimal liver involvement after infection of non-neuroadapted wt RVFV. The gerbil has proven moderately susceptible to RVFV, and the survival rate of 10 -week-old gerbils after s.c. inoculation is reported to range from 50 to $100 \%$, dependent on the strain and inoculation dose [68]. Death was reported to occur around 1 to 3 weeks in a dose-independent manner; s.c. inoculation of $10^{7}$, $10^{5}, 10^{3}, 10^{1} \mathrm{pfu}$ of ZH501 resulted in $90 \%, 100 \%, 60 \%$ and $60 \%$ survival of outbred Tum:(MON) gerbils, respectively, and 50\%, 90\%, 70\% and 70\% survival of inbred MON/Tum gerbils, respectively [68]. The infected gerbils exhibited hind-limb paralysis, generalized weakness and wasting. Gerbils also showed an age-dependent resistance to RVFV infection. Most of the 3- to 5-week-old Tum:(MON) gerbils died after $10^{7}$ pfu s.c. inoculation of ZH501 from encephalitis, whereas $90 \%$ of 7-week-old gerbils were able to survive the infection. After s.c. inoculation, RVFV replicated temporally in the livers of both 4 -week-old and 10-week-old gerbils on days 1 and $2\left(\sim 10^{3} \mathrm{pfu} / \mathrm{g}\right)$, while subsequent efficient virus replication in the brain occurred in 4-week-old gerbil (from day 4 to day 7 up to $10^{7} \mathrm{pfu} / \mathrm{g}$ ), but not in 10-week-old gerbil (temporal increase up to $10^{2}$ at day 7) [68]. Intracerebral wt RVFV inoculation of 50 pfu into 10 -week-old gerbils resulted in an efficient viral replication $\left(\sim 10^{7} \mathrm{pfu} / \mathrm{g}\right)$ in the brain and the mean time to death was six days, which is not statistically different from that of 4-week-old gerbils, which may indicate the presence of host factors influencing the neuroinvasiveness in an age-dependent manner [68]. Histopathologically, minimal multifocal necroses of hepatocytes are seen at days 1 or 2 after the s.c. inoculation of wt RVFV, while focal necrotizing encephalitis with neuronal necrosis, a neutrophilic infiltrate, and perivascular cuffing are 
seen in the brain at later time points [68]. Mild, necrotizing encephalitis without detectable infectious RVFV could be observed even in clinically normal RVF-infected gerbils [68].

\subsection{Nonhuman Primates}

Rhesus macaques are moderately susceptible to RVFV infection [6]. After i.p or intranasal inoculations, body temperatures of infected macaques increased to $39-40{ }^{\circ} \mathrm{C}$ at 1 to 4 days p.i. and the febrile period lasted for 24 to $120 \mathrm{~h}$, whereas some infected animals did not show any febrile reactions [6]. Peters et al. first described hemorrhagic fever-like illness in rhesus macaques that were experimentally infected with a wt RVFV ZH501 strain [69]. Three out of fifteen rhesus macaques intravenously inoculated with RVFV ZH501 became ill; two became moribund and were euthanized on days 7 and 3, and one recovered from illness, whereas the others showed temporal viremia, the maximum viral titer of which occurred around day 2, and were clinically normal. All three monkeys exhibited lassitude, weakness, the cessation of food intake, petechiae, ecchymoses and bleeding from nares, gums or venipuncture sites. Clear extensions of APTT, slight extension of PT, and a decrease in the number of platelets were observed in the two dead monkeys, possibly indicating a deficiency of coagulation factors and platelets. Histopathologically, the dead monkeys showed moderate focal or midzonal coagulative necrosis of the liver involving approximately $1 / 3$ to $2 / 3$ of hepatocytes, necrosis in the ventricular myocardium, fibrin thrombi in the glomeruli and small intertubular vessels of renal medulla in the kidneys, and mild depletion of lymphocytes from white pulp and the deposition of eosinophilic amorphous fibrin-like material in red pulp cords in the spleen [69].

Morrill et al. reported that after intravenous inoculation of $1 \times 10^{5}$ pfu ZH501 strain into 17 rhesus macaques, three developed signs of hemorrhagic fever, seven were clinically ill but survived, and the other seven survived without clinical signs [70]. Serum interferon (IFN)- $\alpha$ was detected from $6-24 \mathrm{~h}$ p.i. and from $24-30 \mathrm{~h}$ p.i. in the surviving monkeys and in those dying, respectively, and the delayed IFN response was preceded by viremia in two of the three lethally-infected monkeys [70]. No surviving monkeys developed signs of encephalitis or retinal complications in follow-up observations at two months to two years [70]. Morrill et al. also demonstrated that the administration of recombinant leukocyte A IFN $\left(5 \times 10^{5} \mathrm{U}\right.$, i.m) at $6 \mathrm{~h}$ after RVFV intravenous inoculation reduced the peak viremia titer by 100 -times and cleared viruses by $48 \mathrm{~h}$ p.i. [71]. These studies suggested the importance of IFN- $\alpha$ in limiting viral replication.

Findlay et al. reported that three species of African monkey, i.e., the green guenon (Cercopithecus callitrichus), the sooty mangabey (Cercocebus fuliginosus) and the Patas guenon (Erythrocebus patas), did not exhibit any febrile reaction after inoculation of RVFV, whereas virus was detected in the blood [72]. In contrast, four species of South American monkeys, two brown capuchin monkeys (Cebus fatuellus and Cebus chrysopus) and two common marmosets (Callithrix jacchus and Callithrix penicillata) exhibited febrile reactions for 1 to 2 days upon RVFV infection, which may indicate that South American monkeys are more susceptible to RVFV infection than African monkeys [72]. Davies et al. reported that RVFV-infected baboons (Papio Anubis) had viremia for 3 to 4 days without developing significant clinical signs [73]. 


\subsection{Sheep}

Daubney et al. originally reported an outbreak of RVF in a herd of sheep in Kenya in 1930, which was characterized as a high rate of abortion in pregnant ewes and high mortality of newborn lambs [4]. A later study by Easterday et al. described that the mortality of adult sheep following experimental RVFV infection was approximately $20 \%$ [74]. Typically, sheep with more than one week old were relatively resistant to RVFV infection, yet did exhibit fever $\left(39\right.$ to $40{ }^{\circ} \mathrm{C}$ ), viremia, diarrhea, nasal discharge, and decreased activity [74,75]. Nine- to ten-week-old young adult sheep (Ripollesa breed) that were subcutaneously inoculated with RVFV had corneal and choroidal edema with inflammatory infiltrate, which could be associated with drainage failure or inadequate corneal dehydration after transient viremia [76]. On the other hand, 7- to 11-month-old Yansaka sheep subcutaneously inoculated with RVFV died during the viremic febrile phase and displayed symptoms of epistaxis (2 days p.i. ), severe and bloody diarrhea, conjunctival hemorrhage, widespread petechiae and ecchymoses in hairless areas, pulmonary edema/hemorrhage, and thrombi formation in the blood vessels of the heart, kidneys and brain. RVFV-infected West African Dwarf or the Ouda breed did not exhibit such rapid hemorrhagic symptoms and rather exhibited marked coagulative hepatic necrosis, and brain lesions, including mild gliosis, neural degeneration, neurophagia, and satellitosis [77]. Interestingly, Yansaka, West African Dwarf and Ouda also had increased prothrombin time, which may have indicated that hemorrhage was induced by a combination of vascular endothelial damage and an inability to clot blood in response to the damage [77]. The inconsistency of symptoms and mortality in adult sheep described in these publications suggest the divergence of host genetic background, even within the same breed of sheep, affects susceptibility to RVFV infection.

Several studies examined the effects of RVFV vaccine candidates for protecting pregnant ewes from wt RVFV infection. However, insufficient immunogenicity of inactivated vaccines or residual virulence of live-attenuated vaccines induced fetal malformations. Pregnant ewes were untreated $(n=8)$ or vaccinated $(n=50)$ once with formalin-inactivated RVFV and then challenged with wt RVFV ZH501 at 45 days post vaccination [78]. Abortion occurred in both unvaccinated and vaccinated ewes, between 6 to 18 days p.i., and $50 \%$ of the ewes aborted their fetuses. One out of 50 vaccinated ewes and one out of eight unvaccinated ewes died. These data may indicate that the inactivated RVFV vaccine induced an insufficient immunity for sheep. Necropsy at 19 days p.i. revealed that $100 \%$ of the ewes had either aborted or dead fetuses, while the dead or aborted lambs showed extensive liver necrosis typical of RVF [78]. Coetzer et al. reported that immunization of pregnant ewes with a live-attenuated Smithburn vaccine strain at 42 to 74 days of pregnancy could cause a teratogenic effect in the fetus, including arthrogryposis, hydranencephaly, or mineralization of brain with or without hydrop amnii, and two out of six lambs from the nine vaccinated ewes showed such effects [79]. Hunter et al. described that pregnant ewes inoculated with live-attenuated MP-12 vaccine strain at 28 to 56 days of gestation either miscarried or produced lambs showing teratogenic effects (11 out of 75 lambs from 50 vaccinated ewes), such as cerebellar hypoplasia, spinal hypoplasia, hydranencephaly, prognathia inferior, brachygnathia inferior, arthrogryposis, scoiliosis, lordosis, kyphosis, or dormed head [80]. The abortion and teratogenous effects did not occur when pregnant ewes were vaccinated with MP-12 at the third trimester of pregnancy, i.e., at 90-110 days of gestation $[81,82]$. On the other hand, pregnant ewes vaccinated at 15 days of gestation with a RVFV Clone 13 
(C13) strain, which has a 69\% in-frame deletion of NSs [83], did not cause abortion or fetal malformations and were protective against wt RVFV challenge [84]. These data may imply the involvement of MP-12 NSs in the abortion of ewes and the teratogenic effects in lambs.

RVFV infection causes an acute and fatal disease in newborn lambs [5]. RVFV-infected newborn lambs usually exhibit obvious illness, including elevated body temperature (40 to $41{ }^{\circ} \mathrm{C}$ ), loss of appetite, decreased activity, and prostration, about 12 to $18 \mathrm{~h}$ prior to death [85]. The mortality rate in RVFV-infected newborn lambs is 95 to $100 \%$ [5]. Studies of experimental infection of 1-4 day-old lambs with RVFV via s.c. resulted in necrosis of isolated hepatocytes (12-18 h p.i.), focal coagulative necrosis of hepatocytes (24-33 h p.i.), and extensive hepatocyte necrosis (48-51 h p.i.) with a progressive increase in viral antigens, whereas no viral antigens could be detected in the endothelial or Kupffer cells in the liver, suggesting that hepatocytes are the primary target of RVFV [86]. The necrosis is predominantly centrilobular or midzonal, and yet there is no definite distribution pattern in liver necrosis $[5,87]$. Some infected lambs also exhibited necrosis in the villi at the distal jejunum and ileum and depletion of lymphocytes in the spleen, whereas the brain and eyes had no lesions [87]. Overall, the liver pathology of newborn lambs resembles that of mice or hamsters, which are extremely susceptible to RVFV. However, the RVFV neurovirulence in lambs is less prominent when compared with that in rodents.

RVFV also causes diseases in other animals including goats, cattle, camels, dogs, cats, and ferrets, but does not cause any symptomatic diseases in rabbits, guinea pigs, birds, horses, pigs and other animals, as reviewed in detail previously [4-6,8,63,88-93]. As of the present, the mechanism of species-specific susceptibility to RVFV infection is unknown.

RVFV infection shows unique pathogenesis in each animal model. Because viral replication and host antiviral responses most probably contribute to viral pathogenecity, an understanding of RVF pathogenesis requires identification and characterization of the viral virulence factors and host antiviral factors. The next chapter describes the viral determinant of virulence.

\section{Viral Determinants of Virulence}

\subsection{Virus Life Cycle}

The RVFV genome is comprised of three RNA segments named the S-, M- and L-segments (Figure 2) [1,2]. The S-segment encodes $\mathrm{N}$ and NSs genes in an ambisense manner, the M-segment. NSm (NSm2), $78 \mathrm{kD}$ (NSm1), Gn and Gc genes, and the L-segment, the RNA-dependent RNA polymerase (L) gene [10]. RVFV virions bind to an unidentified cellular receptor, and enter the cells in a pH-dependent manner [94], probably through a clathrin-mediated endocytic pathway, as described for another phlebovirus [95]. After viral uncoating, viral ribonucleocapsid (RNP) composed of viral genomic RNA segments and N protein [96] is released into the cytoplasm, and the viral polymerase, which probably is attached to the RNP exerts primary transcription to synthesize viral mRNA [97]. Both N mRNA and NSs mRNA are transcribed during primary transcription as early as 40 min after infection from an efficiently packaged, viral-sense (negative-sense) S-segment and anti-viral-sense (positive-sense) S-segment, respectively; the packaging mechanism of RVFV RNP and the presence of specific cis-signals in the genomic RNA are not known [97]. Viral RNA replication starts around 1 to 
$2 \mathrm{~h}$ after infection [97] and an increase in the amount of viral genomic RNA results in increases in viral mRNAs and proteins. The RNP is packaged into viral virions probably by its interaction with the cytoplasmic domains of $\mathrm{Gn} / \mathrm{Gc}$ at the Golgi apparatus, as reported for other bunyaviruses $[98,99]$. The three different RNA segments could be co-packaged in a coordinated manner, in which the co-packaging of M and S-segments could support the packaging of the L-segment [100]. The RVFV virion surface is highly symmetric $\mathrm{T}=12$ icosahedral lattice [101], which is formed by a shell of 122 glycoprotein capsomers most probably composed of $720 \mathrm{Gn}-\mathrm{Gc}$ heterodimers [102].

Figure 2. Schematic representation of Rift Valley fever virus (RVFV) genome structure. S-encodes $\mathrm{N}$ and NSs proteins in an ambisense manner, the M-segment NSm, $78 \mathrm{kD}$ protein $\mathrm{Gn}$ and $\mathrm{Gc}$, and the L-segment L proteins. The $78 \mathrm{kD}$ and NSm proteins are synthesized from 1st and 2nd AUG of M mRNA.

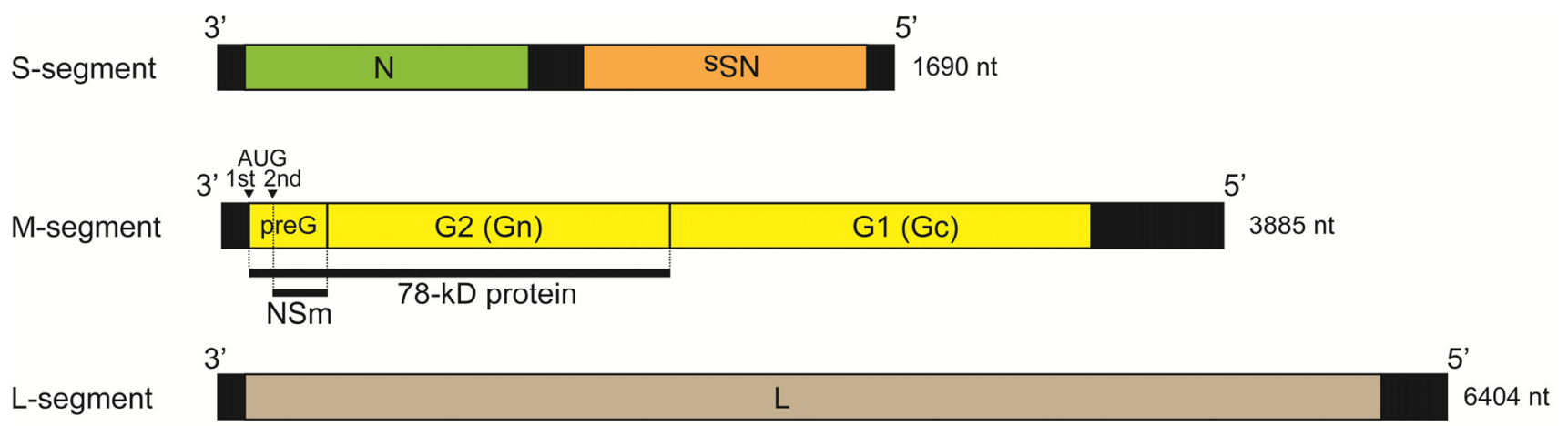

\subsection{Role of NSm Protein in Viral Virulence}

The RVFV M-segment encodes 78 kD, NSm, Gn and Gc proteins in M mRNA (Figure 2). Those proteins are synthesized from a single open reading frame of $\mathrm{M}$ mRNA at different AUGs present at the 5 ' region of $\mathrm{M}$ mRNA by leaky scanning of ribosomes, while the N-terminus of $\mathrm{Gn}$ and $\mathrm{Gc}$ is co-translationally cleaved by host proteins [103-105]. NSm is synthesized from the 2nd AUG, and the $\mathrm{C}$-terminus is generated by cleavage at the N-terminus of $\mathrm{Gn}$, while the $78 \mathrm{kD}$ protein is synthesized from the 1st AUG, and the C-terminus is identical to that of Gn. Among seven viral proteins, NSs and NSm are nonstructural proteins which are not incorporated into virions [59,104]. The $78 \mathrm{kD}$ protein has not been studied in detail, while an " $80 \mathrm{kD}$ " protein induced by RVFV infection (most probably corresponding to the current $78 \mathrm{kD}$ protein) is known to be incorporated into virions [106], which may indicate that the $78 \mathrm{kD}$ protein is a structural protein. NSs, $78 \mathrm{kD}$ protein and NSm are dispensable for viral replication in cell cultures [83,107-109]. Infection of 12-week-old female WF rats with a recombinant RVFV ZH501 strain lacking both $78 \mathrm{kD}$ protein and NSm induced acute fatal hepatic disease, causing the deaths of some infected rats around four days p.i., or a delayed fatal neurologic disease, resulting in death of some of infected animals around 13 days p.i. (mortality rate: 50 to $70 \%$ ), while wt ZH501-infected rats developed acute hepatitis and 100\% died. These data suggest that NSm is not essential for virulence and lethality [110]. On the other hand, a recombinant RVFV MP-12 lacking the expression of both $78 \mathrm{kD}$ and NSm induced more extensive apoptosis than did MP-12 in cultured cells and the expression of NSm significantly inhibited the cleavage of caspase- 8 and -9 
induced by staurosporine [111], demonstrating that NSm protein suppresses apoptosis. Thus, NSm probably suppresses apoptosis in infected hosts and affects viral pathogenicity.

\subsection{Role of NSs Protein in Viral Virulence}

NSs is known to be a major virulence factor of RVFV; a RVFV C13 strain, which has a $69 \%$ in-frame deletion of NSs [83], and is completely attenuated in mice or sheep [51,84]. Further studies showed that NSs inhibits the synthesis of IFN- $\beta$ mRNA under the conditions that transcription factors, such as IFN regulatory factor 3 (IRF-3), NF- $\kappa \mathrm{B}$ and activator protein (AP)-1, are activated in wt RVFV ZH548-infected cells [112]. It was found that NSs can bind and sequester the p44 subunit of TFIIH, an essential transcription factor for RNA polymerase I and II; and hence NSs was reported to prevent the assembly process of the TFIIH complex, resulting in the suppression of host mRNA transcription [113]. Le May et al. also described studies demonstrating that a region of NSs, corresponding to amino acid 210 to 230 , specifically binds to Sin3A-associated protein (SAP30) and forms a complex that represses the histone acetylation required for the transcriptional activation of IFN- $\beta$ promoter; this repression worked even after the binding of IRF-3 to the IFN- $\beta$ promoter [114]; hence, recombinant ZH548 carrying a deletion at amino acid 210 to 230 of NSs cannot suppress the IFN- $\beta$ mRNA synthesis. It should be noted that C13 NSs bound to SAP30, yet it did not suppress IFN- $\beta$ expression [114]. Although the inability of C13 NSs to suppress IFN- $\beta$ expression may have been due to its poor accumulation in infected cells, further studies are required to know how the binding of NSs to SAP30 can lead to the suppression of IFN- $\beta$ mRNA synthesis. It is also uncertain whether the general host transcriptional suppression is required for the inhibition of IFN- $\beta$ mRNA synthesis.

Because NSs induces host general transcription suppression [113], RVFV might have the ability to replicate under host transcription suppression. Actinomycin D (ActD) is a general inhibitor of host RNA synthesis. Viral titers of several cytoplasmic RNA viruses including arenaviruses [115-117], measles virus [118], sindbis virus [119], rubella virus [120], polio virus [121,122], coronaviruses $[123,124]$, and lactic dehydrogenase elevating virus [125] could be reduced in the presence of ActD, while the viral RNA synthesis is often unaffected $[115,118,123]$. We found that expression of NSs protein is essential for the RVFV MP-12 strain to actively synthesize viral proteins and produce high titers of infectious viruses in the presence of ActD [126]; cells infected with recombinant RVFV MP-12 lacking NSs failed to synthesize viral proteins; and while cells infected with MP-12 lacking NSs accumulated phosphorylated eIF2 $\alpha$. The latter made cellular translation initiation inactive through the activation of dsRNA-dependent protein kinase (PKR) at around $8 \mathrm{~h}$ p.i. [126], resulting in the suppression of viral protein synthesis. Further studies revealed that MP-12 NSs promoted the degradation of PKR through the proteasome pathway and prevented an accumulation of phosphorylated eIF2 $\alpha$, thereby securing efficient viral protein synthesis under host transcription shut-off induced by ActD [126]. Habjan et al. reported that wt RVFV NSs also induced PKR degradation and demonstrated that an RVFV C13 strain carrying biologically inactive NSs induced fatal hepatic disease in C57BL/6 mice lacking PKR [127]; these mice are competent for inducing typeI IFNs in response to viral RNA replication or poly (I):poly (C) [128]. PKR is one of several IFN-stimulated genes (ISGs) and plays an important role in inhibiting viral replication in vivo; other 
RNA viruses, including vesicular stomatitis virus (VSV) and influenza virus, also replicate more efficiently in mice lacking PKR than in those with an intact PKR [129]. In addition to PKR, IFN-induced MxA proteins is also known to inhibit RVFV replication [130].

Although the genetic diversity of RVFV strains is relatively low (approximately 5\% in primary sequences [131]), the susceptibilities to rat IFN- $\alpha / \beta$ differed among RVFV strains. Most of the sub-Saharan RVFV strains are very sensitive to rat IFN- $\alpha / \beta\left(\mathrm{ED}_{50}\right.$ : $0.3-0.7$ units), whereas Egyptian strains, including ZH501 and ZH548, and a Zimbabwean isolate (2269/74) are relatively resistant to rat IFN- $\alpha / \beta$ (ED ${ }_{50}: 50-200$ units) [132]. All of those RVFV isolates show a similar sensitivity to human IFN- $\alpha$ (ED 50 : 70-880 units).

In summary, RVFV NSs induces the shut-down of host transcription, including transcription of both type-I IFN and ISGs mRNAs, to prevent antiviral responses. NSs also induces the degradation of PKR to prevent eIF $2 \alpha$-mediated host and viral translational shut-off and promote an efficient viral protein synthesis.

\subsection{Other Virulence Factors}

Although NSs is a major virulence factor to escape host innate immune responses, the virulence of RVFV could be controlled in a polygenic manner. The RVFV MP-12 strain is a highly attenuated strain derived from wt RVFV ZH548 [133] and encodes a functional NSs gene. Mutations in the M- and L-segments are major determinants of MP-12 attenuation [134,135]. In contrast, the C13 strain encodes an S-segment lacking a functional NSs gene, while the M- and L-segments of C13 strain are still virulent phenotypes [51,83]. Mice lacking IFN-AR (IFN-AR ${ }^{-/-}$mice) are susceptible to both MP-12 and C13, while the viral replication kinetics of MP-12 and C13 differ in those mice; the highest titer of viremia was reached within $28 \mathrm{~h}$ p.i. and around $48 \mathrm{~h}$ p.i. in C13-infected mice and in MP-12-infected mice, respectively [51]. Thus, there is a possibility that M- and L-segments of C13 may facilitate a rapid replication of $\mathrm{C} 13$ in these mice, reaching the highest virus titer substantially earlier compared to MP-12-infected mice. Recently, we found that wt RVFV ZH501 virus stock contains two major viral populations, rZH501-M847-A (Glu at aa.123 of Gn protein) and rZH501-M847-G (Gly at the corresponding site); the difference in the amino acid is mapped within one of the neutralizing epitopes in Gn protein [61,136]. Although it is not known how the two different populations have emerged in the ZH501 virus stock, which was amplified once in the mouse brain and passaged twice in FRhL cells and twice in Vero E6 cells, the rZH501-M847G replicated less efficiently than rZH501-M847A in infected mice, whereas both of them replicated efficiently in tissue cultures such as MRC-5, VeroE6, J774.1, and NIH3T3 cells. Our study showed that one amino acid change in the Gn can substantially alter replication and pathogenesis of ZH501 in vivo, and yet the mechanism of the Gn mutation in the pathogenesis remains unknown. Clearly further studies will be needed for understanding the roles of viral proteins in RVFV pathogenesis.

RVFV encodes several virulence factors, and the major virulence factor NSs plays an important role in evading host innate immune responses. In the next chapter, we discuss how humans or host animals develop protective immune responses against highly virulent wt RVFV. 


\section{Host Determinants of Virulence}

\subsection{Host Defense via Infection Route}

Adequate immunity against RVFV can attenuate the virulence of RVFV in animals and vaccination against RVFV can save animals from lethal RVFV challenge [84,133,137-140]. The passive transfer of neutralizing antibodies is sufficient for protection from lethal RVF [67,141-144], whereas the role of the cellular immune response for the protection is not sufficiently evaluated. Yet, Mandell et al. demonstrated that mice immunized with virus-like particles containing $\mathrm{N}$ have a higher survival rate (survival: 9/16) than those not containing $\mathrm{N}$ after lethal RVFV challenges (survival: 3/16). Because anti-N protein antibody is unlikely to neutralize RVFV, these data may point to the involvement of cellular immune responses against $\mathrm{N}$ protein for RVFV protection [145]. Alternatively, antiviral immune responses might be induced by forming a complex between anti-N antibody and $\mathrm{N}$ proteins released from dead cells or infected cells in vivo [146]. If $\mathrm{N}$ proteins are present in cell surface as reported in influenza virus-infected cells $[147,148]$, complement-mediated cell lysis could be another mechanism to support the elimination of infected cells [146].

Aerosol exposure is one of the most likely routes for both laboratory infections and bioterrorism attack. Immunization of rats by s.c. inoculation of a formalin-inactivated RVFV vaccine (TSI-GSD-200) partially protected lethal RVFV aerosol exposure at 187 days post immunization (survival: 72/105: 69\%), whereas 11 out of 72 surviving rats developed encephalitis without clinical signs at 27-28 days post-challenge, which was revealed during necropsy [149]. Another study showed that three vaccinated rats challenged with RVFV aerosol developed uveitis, although no histopathological analysis was presented [141]. Mice are highly susceptible to wt RVFV aerosol exposure $\left(\mathrm{LD}_{50}: 1\right.$ to 2 PFU), which may cause lethal hepatitis, but not pneumonia [150]. A study in mice vaccinated at several different routes with formalin-inactivated RVFV vaccine (NDBR-103) [149] and challenged with RVFV subcutaneously showed that the immunization route affected survival rates; s.c. immunization, intraperitoneal (i.p.) immunization, and intraduodenal (i.d.) immunization resulted in survival rates of $97.5 \%, 100 \%$ and less than $20 \%$, respectively. Another study reported that fewer than $20 \%$ of mice immunized via s.c. or i.d. and about $50 \%$ of mice immunized via i.p. survived after aerosol route challenge of RVFV in the 2-week observation period [151]. Findings from this study using aerosol RVFV challenge indicated that the mucosal immunity elicited by i.d. immunization successfully lowered the occurrence of olfactory bulb encephalitis, but failed to prevent necrotic hepatitis, and immunity induced by s.c. or i.d. did not prevent hepatitis, olfactory bulb encephalitis and multifocal encephalitis, while i.p. immunization completely prevented the occurrence of hepatitis, but not multifocal encephalitis [151]. These reports seem to indicate that immunization with inactivated vaccines via s.c. cannot prevent RVFV-induced diseases after aerosol challenge. It will be important to establish a reliable countermeasure against bioterrorism by use of RVFV through further detailed characterization of RVFV replication in various organs after aerosol challenge and examination of the efficacy of immunization of current live-attenuated RVFV vaccine candidates, such as MP-12 or C13, for preventing RVF-induced diseased after RVFV aerosol challenge.

Exposure of animals to aerosol containing RVFV probably results in initial RVFV infection in lung epithelial cells, such as type I alveolar epithelial cells. Both infection and release of RVFV occur in 
polarized epithelial cells, such as Caco-2 cells (human colorectal adenocarcinoma cells), at apical and basolateral membranes [152]. Infection by Punta Toro virus (PTV), which belongs to the Phlebovirus genus and causes a lethal necrotic hepatitis in hamsters [153,154] and mice [155], results in virus being released into the basolateral membrane [156], which may contribute to systemic viral spread in infected animals.

\subsection{Host Susceptibility}

As described in Section 2.3, several studies point to the possibility that unidentified host genetic factors influence the susceptibility of inbred rat species to RVFV. The primary rat hepatocytes derived from resistant American Lewis rats or $\mathrm{WF} / \mathrm{mol}$ rats are less permissive to RVFV infection than those derived from susceptible American WF rat or Lewis/mol rats [66,157], whereas RVFV replicates efficiently in primary cortical glial cells derived from WF/mol rats [66] or spontaneously transformed cell lines generated from embryonic thymus cells of either resistant LEW rats or susceptible WF rats [132], suggesting that hepatocytes in those resistant inbred rats are under the control of a host factor(s) that restricts efficient RVFV replication. Peritoneal macrophages (PM) derived from resistant Lewis rat or susceptible WF rat were treated with 1.0 or $10 \mathrm{U}$ of IFN, which resulted in a 150- or 3300-fold reduction of ZH501 replication in Lewis PM, and a 4- or 250-fold reduction in WF PM, respectively, possibly indicative of the role of IFN to increase resistance in Lewis rats [158]. On the other hand, primary hepatocytes derived from susceptible Lewis/mol rats and resistant $\mathrm{WF} / \mathrm{mol}$ rats are resistant to RVFV after treatment of the cells with rat type-I IFN, suggesting the resistance induced by type-I IFN is not necessarily important for the host specific resistance seen in WF/mol rats [66].

A recent study showed that MBT/Pas mice, but not BALB/cByi mice, are highly susceptible to RVFV ZH548 infection [159]. Experiments using microarray and quantitative real-time PCR showed that RVFV ZH548 replication in mouse embryonic fibroblast (MEF) cells derived from susceptible $\mathrm{MBT} / \mathrm{Pas}$ mice induced higher levels of Ifnb1 and Ifna4 mRNAs than did those derived from resistant BALB/cByj mice, while MEF cells derived from MBT/Pas mice failed to induce several ISGs, including the IFN regulatory factor 7 (Irf7) mRNA, the 2'-5' oligoadenylate synthetase-like 2 (Oasl2) mRNA, and the IFN-induced $17 \mathrm{kDa}$ protein (Isg15) mRNA [159]. The knockout of Isg15 or Oasl2 mRNA expressions increased viral replication in MEF cells derived from resistant BALB/cByj mice, leading the authors to suggest that MBT/Pas mice have a defect in their IFN responses which controls RVFV spread [159]. It is of interest to know whether the mice lacking Isg15 or Oasl2 genes are susceptible to RVFV. It is unknown whether the susceptibility of inbred rat to RVFV is due to a deficit in some ISGs.

The host factors determining the host susceptibility to PTV infection have been explored; PTV infection in mice mimics RVFV-induced lethal hepatitis. C57BL/6J mice show an age-dependent susceptibility to PTV infection; the mice gradually become resistant to PTV from 5 to 7 weeks, and they are resistant at eight weeks of age [155]. The 8-week-old C57BL/6J mice show a delayed viremia, when compared to 4-week-old mice, and the peak viremia titers in the 8-week-old mice are 5- to 10-times lower than those in the 4-week-old mice [155]. Likewise, PTV replication was lower in primary cultured hepatocytes, Kupffer cells and peripheral blood monocytes isolated from 8-week-old C57BL/6 mice than in those cells obtained from 3-week-old C57BL/6 mice [160,161]. Adding stress 
to the 8-week-old mice by daily handling and observation increased their susceptibility to PTV replication [162]. The role of toll-like receptor (TLR) 3, which is a pathogen recognition receptor recognizing double-stranded RNA, in the susceptibility of the mice to PTV was studied by using 8-week-old TLR3 ${ }^{-/-}$mice of the C57BL/6 background [162]. The wt mice infected with PTV had a $100 \%$ mortality and high levels of IL-6 induction (yet no remarkable increase in TNF- $\alpha$ ), whereas mice lacking TLR3 infected with PTV had increased survival rates, slightly earlier reduction of serum virus titers, and decreased levels of serum IL-6 [162]. On the other hand, IL- $6^{-/-}$mice were more susceptible to PTV infection and supported higher levels of viremia than did wt mice, which possibly means that IL-6 is indispensable for protective immunity. A similar attenuation of virulence has been also reported for West Nile virus infection in $\mathrm{TLR}^{-/-}$mice [163]. The authors hypothesized that over-production of IL-6 in wt mice would be detrimental to the outcome of PTV infection [162], pointing out that the balance of cytokines might alter the pathogenesis of PTV. STAT-1 is a key molecule in the IFN signaling pathway [164]. It was reported that PTV replicated substantially better in the brains of STAT- $1^{-/}$mice than in wt mice. Also PTV titers in sera, spleens and livers of the STAT $-1^{-/}$mice were high, which may emphasize the importance of IFN responses for limiting viral replication in the liver, spleen and brain [165].

\section{Conclusions}

Since the first recognition of RVF in an outbreak in 1930, more than 80 years has passed. Although there has been good progress in characterizing clinical, pathological, and virological features of RVFV infection, RVFV still causes outbreaks in African countries or the Arabian Peninsula [3,10]. The development of effective, safe, highly immunogenic and economic vaccines for animals and humans will prevent RVF in the endemic countries [137]. There are several important questions to address in controlling RVFV and in further understanding RVF pathogenesis. Some of them include determining the: (1) mechanism that triggers hemorrhagic fever, (2) route of viral entry to the brain, (3) mechanism of prolonged diseases in RVF patients in the presence of neutralizing antibodies, and (4) significance of vaccination to prevent RVF after aerosol exposure. Addressing these questions will have a substantial impact on understanding of RVF pathogenesis and development of anti-RVFV reagents.

\section{Acknowledgements}

The authors (TI and SM) were supported by Grant Number 5 U54 AI057156 through the Western Regional Center of Excellence. TI was also supported by R01AI08764301 from the National Institute of Allergy and Infectious Diseases and internal funding from The Sealy Center for Vaccine Development at the University of Texas Medical Branch. SM was also supported by a grant from Department of Homeland Security.

\section{References and Notes}

1. Bishop, D.H.; Calisher, C.H.; Casals, J.; Chumakov, M.P.; Gaidamovich, S.Y.; Hannoun, C.; Lvov, D.K.; Marshall, I.D.; Oker-Blom, N.; Pettersson, R.F.; Porterfield, J.S.; Russell, P.K.; Shope, R.E.; Westaway, E.G. Bunyaviridae. Intervirology 1980, 14, 125-143. 
2. Schmaljohn, C.; Nichol, S.T. Bunyaviridae. In Fields Virology, 5th ed; Knipe, D.M., Howley, P.M., Griffin, D.E., Lamb, R.A., Martin, M.A., Roizman, B., Straus, S.E., Eds. Lippincott, Williams \& Wilkins: Philadelphia, PA, USA, 2007; pp. 1741-1789.

3. Bird, B.H.; Ksiazek, T.G.; Nichol, S.T.; Maclachlan, N.J. Rift valley fever virus. J. Am. Vet. Med. Assoc. 2009, 234, 883-893.

4. Daubney, R.; Hudson, J.R. Enzootic hepatitis or rift valley fever: An undescribed virus disease of sheep cattle and man from east Africa. J. Path. Bact. 1931, 34, 545-579.

5. Easterday, B.C. Rift valley fever. Adv. Vet. Sci. 1965, 10, 65-127.

6. Findlay, G.M.; Daubney, R. The virus of rift valley fever or enzootic hepatitis. Lancet 1931, 221, 1350-1351.

7. Peters, C.J.; Meegan, J.M. Rift valley fever. In Handbook Series of Zoonoses, Section B: Viral Zoonoses; CRC Press: Boca Raton, FL, USA, 1981; Volume 1, pp. 403-420.

8. Weiss, K.E. Rift valley fever-a review. Bull. Epz. Dis. Afr. 1957, 5, 431-458.

9. Linthicum, K.J.; Davies, F.G.; Kairo, A.; Bailey, C.L. Rift valley fever virus (family bunyaviridae, genus phlebovirus). Isolations from diptera collected during an inter-epizootic period in kenya. J. Hyg. (Lond.) 1985, 95, 197-209.

10. Pepin, M.; Bouloy, M.; Bird, B.H.; Kemp, A.; Paweska, J. Rift valley fever virus (bunyaviridae: Phlebovirus): An update on pathogenesis, molecular epidemiology, vectors, diagnostics and prevention. Vet. Res. 2010, 41, 61.

11. Thonnon, J.; Picquet, M.; Thiongane, Y.; Lo, M.; Sylla, R.; Vercruysse, J. Rift valley fever surveillance in the lower senegal river basin: Update 10 years after the epidemic. Trop. Med. Int. Health 1999, 4, 580-585.

12. Anyangu, A.S.; Gould, L.H.; Sharif, S.K.; Nguku, P.M.; Omolo, J.O.; Mutonga, D.; Rao, C.Y.; Lederman, E.R.; Schnabel, D.; Paweska, J.T.; Katz, M.; Hightower, A.; Njenga, M.K.; Feikin, D.R.; Breiman, R.F. Risk factors for severe rift valley fever infection in kenya, 2007. Am. J. Trop. Med. Hyg. 2010, 83, 14-21.

13. Andriamandimby, S.F.; Randrianarivo-Solofoniaina, A.E.; Jeanmaire, E.M.; Ravololomanana, L.; Razafimanantsoa, L.T.; Rakotojoelinandrasana, T.; Razainirina, J.; Hoffmann, J.; Ravalohery, J.P.; Rafisandratantsoa, J.T.; Rollin, P.E.; Reynes, J.M. Rift valley fever during rainy seasons, madagascar, 2008 and 2009. Emerg. Infect. Dis. 2010, 16, 963-970.

14. Linthicum, K.J.; Anyamba, A.; Tucker, C.J.; Kelley, P.W.; Myers, M.F.; Peters, C.J. Climate and satellite indicators to forecast rift valley fever epidemics in kenya. Science 1999, 285, 397-400.

15. Anyamba, A.; Chretien, J.P.; Small, J.; Tucker, C.J.; Formenty, P.B.; Richardson, J.H.; Britch, S.C.; Schnabel, D.C.; Erickson, R.L.; Linthicum, K.J. Prediction of a rift valley fever outbreak. Proc. Natl. Acad. Sci. U. S. A. 2009, 106, 955-959.

16. Abu-Elyazeed, R.; el-Sharkawy, S.; Olson, J.; Botros, B.; Soliman, A.; Salib, A.; Cummings, C.; Arthur, R. Prevalence of anti-rift-valley-fever igm antibody in abattoir workers in the nile delta during the 1993 outbreak in egypt. Bull. World Health Organ. 1996, 74, 155-158.

17. Swai, E.S.; Schoonman, L. Prevalence of rift valley fever immunoglobulin $g$ antibody in various occupational groups before the 2007 outbreak in tanzania. Vector Borne Zoonotic Dis. 2009, 9, 579-582. 
18. Turell, M.J.; Gargan, T.P., 2nd; Bailey, C.L. Replication and dissemination of rift valley fever virus in culex pipiens. Am. J. Trop. Med. Hyg. 1984, 33, 176-181.

19. Gargan, T.P., 2nd; Clark, G.G.; Dohm, D.J.; Turell, M.J.; Bailey, C.L. Vector potential of selected north american mosquito species for rift valley fever virus. Am. J. Trop. Med. Hyg. 1988, 38, 440-446.

20. Turell, M.J.; Bailey, C.L.; Beaman, J.R. Vector competence of a houston, texas strain of aedes albopictus for rift valley fever virus. J. Am. Mosq. Control Assoc. 1988, 4, 94-96.

21. Schwentker, F.F.; Rivers, T.M. Report of a fatal laboratory infection complicated by thrombophlebitis. J. Exp. Med. 1933, 59, 305-313.

22. Kitchen, S.F. Laboratory infections with the virus of rift valley fever Am. J. Trop. Med. 1934, 14, 547-564.

23. Francis, T.; Magill, T.P. Rift valley fever : A report of three cases of laboratory infection and the experimental transmission of the disease to ferrets. J. Exp. Med. 1935, 62, 433-448.

24. Sabin, A.B.; Blumberg, R.W. Human infection with rift valley fever virus and immunity twelve years after single attack. Proc. Soc. Exp. Biol. Med. 1947, 64, 385-389.

25. Smithburn, K.C.; Mahaffy, A.F.; et al. Rift valley fever; accidental infections among laboratory workers. J. Immunol. 1949, 62, 213-227.

26. Mundel, B.; Gear, J. Rift valley fever; i. The occurrence of human cases in johannesburg. S. Afr. Med. J. 1951, 25, 797-800.

27. Gear, J.; De Meillon, B.; Measroch, V.; Davis, D.H.; Harwin, H. Rift valley fever in south africa. 2. The occurrence of human cases in the orange free state, the north-western cape province, the western and southern transvaal. B. Field and laboratory investigation. S. Afr. Med. J. 1951, 25, 908-912.

28. Joubert, J.D.; Ferguson, A.L.; Gear, J. Rift valley fever in south africa: 2. The occurrence of human cases in the orange free state, the north-western cape province, the western and southern transvaal. A epidemiological and clinical findings. S. Afr. Med. J. 1951, 25, 890-891.

29. Maar, S.A.; Swanepoel, R.; Gelfand, M. Rift valley fever encephalitis. A description of a case. Cent. Afr. J. Med. 1979, 25, 8-11.

30. Alrajhi, A.A.; Al-Semari, A.; Al-Watban, J. Rift valley fever encephalitis. Emerg. Infect. Dis. 2004, 10, 554-555.

31. Laughlin, L.W.; Girgis, N.I.; Meegan, J.M.; Strausbaugh, L.J.; Yassin, M.W.; Watten, R.H. Clinical studies on rift valley fever. Part 2: Ophthalmologic and central nervous system complications. J. Egypt. Publ. Health Assoc. 1978, 53, 183-184.

32. van Velden, D.J.; Meyer, J.D.; Olivier, J.; Gear, J.H.; McIntosh, B. Rift valley fever affecting humans in south africa: A clinicopathological study. S. Afr. Med. J. 1977, 51, 867-871.

33. Siam, A.L.; Meegan, J.M.; Gharbawi, K.F. Rift valley fever ocular manifestations: Observations during the 1977 epidemic in egypt. Br. J. Ophthalmol. 1980, 64, 366-374.

34. Salib, M.; Sobhy, M.I. Epidemic maculopathy. Bull. Ophthalmol. Soc. Egypt 1978, 71, 103-106.

35. Deutman, A.F.; Klomp, H.J. Rift valley fever retinitis. Am. J. Ophthalmol. 1981, 92, 38-42.

36. Schrire, L. Macular changes in rift valley fever. S. Afr. Med. J. 1951, 25, 926-930.

37. Freed, I. Rift valley fever in man, complicated by retinal changes and loss of vision. S. Afr. Med. J. 1951, 25, 930-932. 
38. Siam, A.L.; Meegan, J.M. Ocular disease resulting from infection with rift valley fever virus. Trans. R. Soc. Trop. Med. Hyg. 1980, 74, 539-541.

39. Al-Hazmi, A.; Al-Rajhi, A.A.; Abboud, E.B.; Ayoola, E.A.; Al-Hazmi, M.; Saadi, R.; Ahmed, N. Ocular complications of rift valley fever outbreak in saudi arabia. Ophthalmology 2005, 112, 313-318.

40. Siam, A.L.; Gharbawi, K.F.; Meegan, J.M. Ocular complications of rift valley fever. J. Egypt. Publ. Health Assoc. 1978, 53, 185-186.

41. Ayoub, M.; Barhoma, G.; Zaghlol, I. Ocular manifestations of rift valley fever. Bull. Ophthalmol. Soc. Egypt 1978, 71, 125-133.

42. Swanepoel, R.; Manning, B.; Watt, J.A. Fatal rift valley fever of man in rhodesia. Cent. Afr. J. Med. 1979, 25, 1-8.

43. Yassin, W. Clinico-pathological picture in five human cases died with rift valley fever. J. Egypt. Publ. Health Assoc. 1978, 53, 191-193.

44. Abdel-Wahab, K.S.; El Baz, L.M.; El-Tayeb, E.M.; Omar, H.; Ossman, M.A.; Yasin, W. Rift valley fever virus infections in egypt: Pathological and virological findings in man. Trans. R. Soc. Trop. Med. Hyg. 1978, 72, 392-396.

45. Al-Hazmi, M.; Ayoola, E.A.; Abdurahman, M.; Banzal, S.; Ashraf, J.; El-Bushra, A.; Hazmi, A.; Abdullah, M.; Abbo, H.; Elamin, A.; Al-Sammani el, T.; Gadour, M.; Menon, C.; Hamza, M.; Rahim, I.; Hafez, M.; Jambavalikar, M.; Arishi, H.; Aqeel, A. Epidemic rift valley fever in saudi arabia: A clinical study of severe illness in humans. Clin. Infect. Dis. 2003, 36, 245-252.

46. Al-Khuwaitir, T.S.; Al-Moghairi, A.M.; Sherbeeni, S.M.; Al-Ghamdi, A.S. Rift valley fever hepatitis complicated by disseminated intravascular coagulation and hepatorenal syndrome. Saudi Med. J. 2004, 25, 528-531.

47. El Imam, M.; El Sabiq, M.; Omran, M.; Abdalkareem, A.; El Gaili Mohamed, M.A.; Elbashir, A.; Khalafala, O. Acute renal failure associated with the rift valley fever: A single center study. Saudi J. Kidney Dis. Transpl. 2009, 20, 1047-1052.

48. Abdel-Aziz, A.A.; Meegan, J.M.; Laughlin, L.W. Rift valley fever as a possible cause of human abortions. Trans. R. Soc. Trop. Med. Hyg. 1980, 74, 685-686.

49. Arishi, H.M.; Aqeel, A.Y.; Al Hazmi, M.M. Vertical transmission of fatal rift valley fever in a newborn. Ann. Trop. Paediatr. 2006, 26, 251-253.

50. Vialat, P.; Billecocq, A.; Kohl, A.; Bouloy, M. The s segment of rift valley fever phlebovirus (bunyaviridae) carries determinants for attenuation and virulence in mice. J. Virol. 2000, 74, 1538-1543.

51. Bouloy, M.; Janzen, C.; Vialat, P.; Khun, H.; Pavlovic, J.; Huerre, M.; Haller, O. Genetic evidence for an interferon-antagonistic function of rift valley fever virus nonstructural protein nss. J. Virol. 2001, 75, 1371-1377.

52. Smith, D.R.; Steele, K.E.; Shamblin, J.; Honko, A.; Johnson, J.; Reed, C.; Kennedy, M.; Chapman, J.L.; Hensley, L.E. The pathogenesis of rift valley fever virus in the mouse model. Virology 2010, 407, 256-267.

53. Mims, C.A. Rift valley fever virus in mice. Iii. Further quantitative features of the infective process. Br. J. Exp. Pathol. 1956, 37, 120-128. 
54. Mims, C.A. Rift valley fever virus in mice. I. General features of the infection. Br. J. Exp. Pathol. 1956, 37, 99-109.

55. McGavran, M.H.; Easterday, B.C. Rift valley fever virus hepatitis: Light and electron microscopic studies in the mouse. Am. J. Pathol. 1963, 42, 587-607.

56. Tomori, O.; Kasali, O. Pathogenicity of different strains of rift valley fever virus in swiss albino mice. Br. J. Exp. Pathol. 1979, 60, 417-422.

57. Chieco, P.; Derenzini, M. The feulgen reaction 75 years on. Histochem. Cell Biol. 1999, 111, 345-358.

58. Swanepoel, R.; Blackburn, N.K. Demonstration of nuclear immunofluorescence in rift valley fever infected cells. J. Gen. Virol. 1977, 34, 557-561.

59. Struthers, J.K.; Swanepoel, R. Identification of a major non-structural protein in the nuclei of rift valley fever virus-infected cells. J. Gen. Virol. 1982, 60, 381-384.

60. Yadani, F.Z.; Kohl, A.; Prehaud, C.; Billecocq, A.; Bouloy, M. The carboxy-terminal acidic domain of rift valley fever virus nss protein is essential for the formation of filamentous structures but not for the nuclear localization of the protein. J. Virol. 1999, 73, 5018-5025.

61. Morrill, J.C.; Ikegami, T.; Yoshikawa-Iwata, N.; Lokugamage, N.; Won, S.; Terasaki, K.; Zamoto-Niikura, A.; Peters, C.J.; Makino, S. Rapid accumulation of virulent rift valley fever virus in mice from an attenuated virus carrying a single nucleotide substitution in the m rna. PLOS ONE 5 , e9986.

62. Findlay, G.M.; Howard, E.M. The susceptibility of rats to rift valley fever in relation to age. Ann. Trop. Med. Parasitol. 1952, 46, 33-37.

63. Peters, C.J.; Anderson, G.W.J. Pathogenesis of rift valley fever. Contr. Epidem. Biostatist. 1981, $3,21-41$.

64. Peters, C.J.; Slone, T.W. Inbred rat strains mimic the disparate human response to rift valley fever virus infection. J. Med. Virol. 1982, 10, 45-54.

65. Anderson, G.W., Jr.; Slone, T.W., Jr.; Peters, C.J. Pathogenesis of rift valley fever virus (rvfv) in inbred rats. Microb. Pathog. 1987, 2, 283-293.

66. Ritter, M.; Bouloy, M.; Vialat, P.; Janzen, C.; Haller, O.; Frese, M. Resistance to rift valley fever virus in rattus norvegicus: Genetic variability within certain 'inbred' strains. J. Gen. Virol. 2000, $81,2683-2688$.

67. Niklasson, B.S.; Meadors, G.F.; Peters, C.J. Active and passive immunization against rift valley fever virus infection in syrian hamsters. Acta Pathol. Microbiol. Immunol. Scand. [C] 1984, 92, 197-200.

68. Anderson, G.W., Jr.; Slone, T.W., Jr.; Peters, C.J. The gerbil, meriones unguiculatus, a model for rift valley fever viral encephalitis. Arch. Virol. 1988, 102, 187-196.

69. Peters, C.J.; Jones, D.; Trotter, R.; Donaldson, J.; White, J.; Stephen, E.; Slone, T.W., Jr. Experimental rift valley fever in rhesus macaques. Arch. Virol. 1988, 99, 31-44.

70. Morrill, J.C.; Jennings, G.B.; Johnson, A.J.; Cosgriff, T.M.; Gibbs, P.H.; Peters, C.J. Pathogenesis of rift valley fever in rhesus monkeys: Role of interferon response. Arch. Virol. 1990, 110, $195-212$.

71. Morrill, J.C.; Jennings, G.B.; Cosgriff, T.M.; Gibbs, P.H.; Peters, C.J. Prevention of rift valley fever in rhesus monkeys with interferon-alpha. Rev. Infect. Dis. 1989, 11, S815-825. 
72. Findlay, G.M. The infectivity of rift valley fever for monkeys. Trans. Roy. Soc. Trop. Med. Hyg. 1932, 26, 161-168.

73. Davies, F.G.; Clausen, B.; Lund, L.J. The pathogenicity of rift valley fever virus for the baboon. Trans. R. Soc. Trop. Med. Hyg. 1972, 66, 363-365.

74. Easterday, B.C.; Murphy, L.C.; Bennett, D.G. Experimental rift valley fever in lambs and sheeps. Am. J. Vet. Res. 1962, 23, 1231-1240.

75. Tomori, O. Clinical, virological and serological response of the west african dwarf sheep to experimental infection with different strains of rift valley fever virus. Res. Vet. Sci. 1979, 26, $152-159$.

76. Busquets, N.; Xavier, F.; Martin-Folgar, R.; Lorenzo, G.; Galindo-Cardiel, I.; del Val, B.P.; Rivas, R.; Iglesias, J.; Rodriguez, F.; Solanes, D.; Domingo, M.; Brun, A. Experimental infection of young adult european breed sheep with rift valley fever virus field isolates. Vector Borne Zoonotic Dis. 2010, 10, 689-696.

77. Olaleye, O.D.; Tomori, O.; Fajimi, J.L.; Schmitz, H. Experimental infection of three nigerian breeds of sheep with the zinga strain of the rift valley fever virus. Rev. Elev. Med. Vet. Pays. Trop. 1996, 49, 6-16.

78. Yedloutschnig, R.J.; Dardiri, A.H.; Mebus, C.A.; Walker, J.S. Abortion in vaccinated sheep and cattle after challenge with rift valley fever virus. Vet. Rec. 1981, 109, 383-384.

79. Coetzer, J.A.; Barnard, B.J. Hydrops amnii in sheep associated with hydranencephaly and arthrogryposis with wesselsbron disease and rift valley fever viruses as aetiological agents. Onderstepoort J. Vet. Res. 1977, 44, 119-126.

80. Hunter, P.; Erasmus, B.J.; Vorster, J.H. Teratogenicity of a mutagenised rift valley fever virus (mvp 12) in sheep. Onderstepoort J. Vet. Res. 2002, 69, 95-98.

81. Morrill, J.C.; Carpenter, L.; Taylor, D.; Ramsburg, H.H.; Quance, J.; Peters, C.J. Further evaluation of a mutagen-attenuated rift valley fever vaccine in sheep. Vaccine 1991, 9, 35-41.

82. Morrill, J.C.; Jennings, G.B.; Caplen, H.; Turell, M.J.; Johnson, A.J.; Peters, C.J. Pathogenicity and immunogenicity of a mutagen-attenuated rift valley fever virus immunogen in pregnant ewes. Am. J. Vet. Res. 1987, 48, 1042-1047.

83. Muller, R.; Saluzzo, J.F.; Lopez, N.; Dreier, T.; Turell, M.; Smith, J.; Bouloy, M. Characterization of clone 13, a naturally attenuated avirulent isolate of rift valley fever virus, which is altered in the small segment. Am. J. Trop. Med. Hyg. 1995, 53, 405-411.

84. Dungu, B.; Louw, I.; Lubisi, A.; Hunter, P.; von Teichman, B.F.; Bouloy, M. Evaluation of the efficacy and safety of the rift valley fever clone 13 vaccine in sheep. Vaccine 2010, 28, 4581-4587.

85. Easterday, B.C.; Mc, G.M.; Rooney, J.R.; Murphy, L.C. The pathogenesis of rift valley fever in lambs. Am. J. Vet. Res. 1962, 23, 470-479.

86. Van der Lugt, J.J.; Coetzer, J.A.; Smit, M.M. Distribution of viral antigen in tissues of new-born lambs infected with rift valley fever virus. Onderstepoort J. Vet. Res. 1996, 63, 341-347.

87. Coetzer, J.A. The pathology of rift valley fever. I. Lesions occurring in natural cases in new-born lambs. Onderstepoort J. Vet. Res. 1977, 44, 205-211. 
88. Walker, J.S.; Remmele, N.S.; Carter, R.C.; Mitten, J.Q.; Schuh, L.G.; Stephen, E.L.; Klein, F. The clinical aspects of rift valley fever virus in household pets. I. Susceptibility of the dog. J. Infect. Dis. 1970, 121, 9-18.

89. Walker, J.S.; Stephen, E.L.; Remmele, N.S.; Carter, R.C.; Mitten, J.Q.; Schuh, L.G.; Klein, F. The clinical aspects of rift valley fever virus in household pets. Ii. Susceptibility of the cat. J. Infect. Dis. 1970, 121, 19-24.

90. Keefer, G.V.; Zebarth, G.L.; Allen, W.P. Susceptibility of dogs and cats to rift valley fever by inhalation or ingestion of virus. J. Infect. Dis. 1972, 125, 307-309.

91. Scott, G.R. Pigs and rift valley fever. Nature 1963, 200, 919-920.

92. Scott, G.R.; Coackley, W.; Roach, R.W.; Cowdy, N.R. Rift valley fever in camels. J. Pathol. Bacteriol. 1963, 86, 229-231.

93. Shimshony, A.; Barzilai, R. Rift valley fever. Adv. Vet. Sci. Comp Med 1983, 27, 347-425.

94. Filone, C.M.; Heise, M.; Doms, R.W.; Bertolotti-Ciarlet, A. Development and characterization of a rift valley fever virus cell-cell fusion assay using alphavirus replicon vectors. Virology 2006, 356, 155-164.

95. Lozach, P.Y.; Mancini, R.; Bitto, D.; Meier, R.; Oestereich, L.; Overby, A.K.; Pettersson, R.F.; Helenius, A. Entry of bunyaviruses into mammalian cells. Cell Host Microbe 2010, 7, 488-499.

96. Raymond, D.D.; Piper, M.E.; Gerrard, S.R.; Smith, J.L. Structure of the rift valley fever virus nucleocapsid protein reveals another architecture for rna encapsidation. Proc. Natl. Acad. Sci. U. S. A. 2010, 107, 11769-11774.

97. Ikegami, T.; Won, S.; Peters, C.J.; Makino, S. Rift valley fever virus nss mrna is transcribed from an incoming anti-viral-sense s rna segment. J. Virol. 2005, 79, 12106-12111.

98. Shi, X.; Kohl, A.; Li, P.; Elliott, R.M. Role of the cytoplasmic tail domains of bunyamwera orthobunyavirus glycoproteins gn and gc in virus assembly and morphogenesis. J. Virol. 2007, 81, 10151-10160.

99. Overby, A.K.; Pettersson, R.F.; Neve, E.P. The glycoprotein cytoplasmic tail of uukuniemi virus (bunyaviridae) interacts with ribonucleoproteins and is critical for genome packaging. J. Virol. 2007, 81, 3198-3205.

100. Terasaki, K.; Murakami, S.; Lokugamage, K.G.; Makino, S. Mechanism of tripartite rna genome packaging in rift valley fever virus. Proc. Natl. Acad. Sci. U. S. A. 108, 804-809.

101. Freiberg, A.N.; Sherman, M.B.; Morais, M.C.; Holbrook, M.R.; Watowich, S.J. Threedimensional organization of rift valley fever virus revealed by cryoelectron tomography. J. Virol. 2008, 82, 10341-10348.

102. Huiskonen, J.T.; Overby, A.K.; Weber, F.; Grunewald, K. Electron cryo-microscopy and singleparticle averaging of rift valley fever virus: Evidence for gn-gc glycoprotein heterodimers. $J$. Virol. 2009, 83, 3762-3769.

103. Kakach, L.T.; Suzich, J.A.; Collett, M.S. Rift valley fever virus $m$ segment: Phlebovirus expression strategy and protein glycosylation. Virology 1989, 170, 505-510.

104. Kakach, L.T.; Wasmoen, T.L.; Collett, M.S. Rift valley fever virus $m$ segment: Use of recombinant vaccinia viruses to study phlebovirus gene expression. J. Virol. 1988, 62, 826-833. 
105. Gerrard, S.R.; Nichol, S.T. Synthesis, proteolytic processing and complex formation of nterminally nested precursor proteins of the rift valley fever virus glycoproteins. Virology 2007, $357,124-133$.

106. Struthers, J.K.; Swanepoel, R.; Shepherd, S.P. Protein synthesis in rift valley fever virus-infected cells. Virology 1984, 134, 118-124.

107. Won, S.; Ikegami, T.; Peters, C.J.; Makino, S. Nsm and 78-kilodalton proteins of rift valley fever virus are nonessential for viral replication in cell culture. J. Virol. 2006, 80, 8274-8278.

108. Gerrard, S.R.; Bird, B.H.; Albarino, C.G.; Nichol, S.T. The nsm proteins of rift valley fever virus are dispensable for maturation, replication and infection. Virology 2007, 359, 459-465.

109. Ikegami, T.; Won, S.; Peters, C.J.; Makino, S. Rescue of infectious rift valley fever virus entirely from cdna, analysis of virus lacking the nss gene, and expression of a foreign gene. J. Virol. 2006, 80, 2933-2940.

110. Bird, B.H.; Albarino, C.G.; Nichol, S.T. Rift valley fever virus lacking nsm proteins retains high virulence in vivo and may provide a model of human delayed onset neurologic disease. Virology 2007, 362, 10-15.

111. Won, S.; Ikegami, T.; Peters, C.J.; Makino, S. Nsm protein of rift valley fever virus suppresses virus-induced apoptosis. J. Virol. 2007, 81, 13335-13345.

112. Billecocq, A.; Spiegel, M.; Vialat, P.; Kohl, A.; Weber, F.; Bouloy, M.; Haller, O. Nss protein of rift valley fever virus blocks interferon production by inhibiting host gene transcription. J. Virol. 2004, 78, 9798-9806.

113. Le May, N.; Dubaele, S.; Proietti De Santis, L.; Billecocq, A.; Bouloy, M.; Egly, J.M. Tfiih transcription factor, a target for the rift valley hemorrhagic fever virus. Cell 2004, 116, 541-550.

114. Le May, N.; Mansuroglu, Z.; Leger, P.; Josse, T.; Blot, G.; Billecocq, A.; Flick, R.; Jacob, Y.; Bonnefoy, E.; Bouloy, M. A sap30 complex inhibits ifn-beta expression in rift valley fever virus infected cells. PLoS Pathog. 2008, 4, e13.

115. Bushar, G.; Sagripanti, J.L. Replication and physical parameters important for preparing purified junin virus. J. Virol. Methods 1993, 41, 147-156.

116. Rawls, W.E.; Banerjee, S.N.; McMillan, C.A.; Buchmeier, M.J. Inhibition of pichinde virus replication by actinomycin d. J. Gen. Virol. 1976, 33, 421-434.

117. Buck, L.L.; Pfau, C.J. Inhibition of lymphocytic choriomeningitis virus replication by actinomycin d and 6-azauridine. Virology 1969, 37, 698-701.

118. Hall, W.W.; ter Meulen, V. The effects of actinomycin d on rna synthesis in measles virus-infected cells. J. Gen. Virol. 1977, 34, 391-396.

119. Baric, R.S.; Carlin, L.J.; Johnston, R.E. Requirement for host transcription in the replication of sindbis virus. J. Virol. 1983, 45, 200-205.

120. Nakhasi, H.L.; Zheng, D.X.; Hewlett, I.K.; Liu, T.Y. Rubella virus replication: Effect of interferons and actinomycin d. Virus Res. 1988, 10, 1-15.

121. Grado, C.; Ohlbaum, A. The effect of rifampicin, actinomycin $\mathrm{d}$ and mitomycin $\mathrm{c}$ on poliovirus and foot-and-mouth disease virus replication. J. Gen. Virol. 1973, 21, 297-303.

122. Grado, C.; Fischer, S.; Contreras, G. The inhibition by actinomycin d of poliovirus multiplication hep 2 cells. Virology 1965, 27, 623-625. 
123. Kennedy, D.A.; Johnson-Lussenburg, C.M. Inhibition of coronavirus 229e replication by actinomycin d. J. Virol. 1979, 29, 401-404.

124. Lewis, E.L.; Harbour, D.A.; Beringer, J.E.; Grinsted, J. Differential in vitro inhibition of feline enteric coronavirus and feline infectious peritonitis virus by actinomycin d. J. Gen. Virol. 1992, 73, 3285-3288.

125. Yamazaki, S.; Notkins, A.L. Inhibition of replication of lactic dehydrogenase virus by actinomycin. $J$. Virol. 1973, 11, 473-478.

126. Ikegami, T.; Narayanan, K.; Won, S.; Kamitani, W.; Peters, C.J.; Makino, S. Rift valley fever virus nss protein promotes post-transcriptional downregulation of protein kinase pkr and inhibits eif2alpha phosphorylation. PLoS Pathog. 2009, 5, e1000287.

127. Habjan, M.; Pichlmair, A.; Elliott, R.M.; Overby, A.K.; Glatter, T.; Gstaiger, M.; Superti-Furga, G.; Unger, H.; Weber, F. Nss protein of rift valley fever virus induces the specific degradation of the double-stranded rna-dependent protein kinase. J. Virol. 2009, 83, 4365-4375.

128. Yang, Y.L.; Reis, L.F.; Pavlovic, J.; Aguzzi, A.; Schafer, R.; Kumar, A.; Williams, B.R.; Aguet, M.; Weissmann, C. Deficient signaling in mice devoid of double-stranded rna-dependent protein kinase. EMBO J. 1995, 14, 6095-6106.

129. Balachandran, S.; Roberts, P.C.; Brown, L.E.; Truong, H.; Pattnaik, A.K.; Archer, D.R.; Barber, G.N. Essential role for the dsrna-dependent protein kinase $\mathrm{pkr}$ in innate immunity to viral infection. Immunity 2000, 13, 129-141.

130. Frese, M.; Kochs, G.; Feldmann, H.; Hertkorn, C.; Haller, O. Inhibition of bunyaviruses, phleboviruses, and hantaviruses by human mxa protein. J. Virol. 1996, 70, 915-923.

131. Bird, B.H.; Khristova, M.L.; Rollin, P.E.; Ksiazek, T.G.; Nichol, S.T. Complete genome analysis of 33 ecologically and biologically diverse rift valley fever virus strains reveals widespread virus movement and low genetic diversity due to recent common ancestry. J. Virol. 2007, 81, 2805-2816.

132. Anderson, G.W., Jr.; Peters, C.J. Viral determinants of virulence for rift valley fever (rvf) in rats. Microb. Pathog. 1988, 5, 241-250.

133. Caplen, H.; Peters, C.J.; Bishop, D.H. Mutagen-directed attenuation of rift valley fever virus as a method for vaccine development. J. Gen. Virol. 1985, 66, 2271-2277.

134. Billecocq, A.; Gauliard, N.; Le May, N.; Elliott, R.M.; Flick, R.; Bouloy, M. Rna polymerase i-mediated expression of viral rna for the rescue of infectious virulent and avirulent rift valley fever viruses. Virology 2008, 378, 377-384.

135. Ikegami, T.; Morrill, J. C.; Peters, C.J.; Makino, S. Reassortant RVFV between MP-12 and ZH501 by reverese genetics. The University of Texas Medical Branch, Galveston, TX, USA; Unpublished work, 2011.

136. Keegan, K.; Collett, M.S. Use of bacterial expression cloning to define the amino acid sequences of antigenic determinants on the g2 glycoprotein of rift valley fever virus. J. Virol. 1986, 58, 263-270.

137. Ikegami, T.; Makino, S. Rift valley fever vaccines. Vaccine 2009, 27, D69-D72.

138. Randall, R.; Binn, L.N.; Harrison, V.R. Immunization against rift valley fever virus. Studies onthe immunogenicity of lyophilized formalin-inactivated vaccine. J. Immunol. 1964, 93, 293-299. 
139. Randall, R.; Gibbs, C.J., Jr.; Aulisio, C.G.; Binn, L.N.; Harrison, V.R. The development of a formalin-killed rift valley fever virus vaccine for use in man. J. Immunol. 1962, 89, 660-671.

140. Smithburn, K.C. Rift valley fever; the neurotropic adaptation of the virus and the experimental use of this modified virus as a vaccine. Br. J. Exp. Pathol. 1949, 30, 1-16.

141. Anderson, G.W., Jr.; Lee, J.O.; Anderson, A.O.; Powell, N.; Mangiafico, J.A.; Meadors, G. Efficacy of a rift valley fever virus vaccine against an aerosol infection in rats. Vaccine 1991, 9 , $710-714$.

142. Schmaljohn, C.S.; Parker, M.D.; Ennis, W.H.; Dalrymple, J.M.; Collett, M.S.; Suzich, J.A.; Schmaljohn, A.L. Baculovirus expression of the $\mathrm{m}$ genome segment of rift valley fever virus and examination of antigenic and immunogenic properties of the expressed proteins. Virology 1989, 170, 184-192.

143. Harrington, D.G.; Lupton, H.W.; Crabbs, C.L.; Peters, C.J.; Reynolds, J.A.; Slone, T.W., Jr. Evaluation of a formalin-inactivated rift valley fever vaccine in sheep. Am. J. Vet. Res. 1980, 41, 1559-1564.

144. Kasahara, S.; Koyama, H. Long term existence of rift valley fever virus in immune mice. Kitasato Arch. Exp. Med. 1973, 46, 105-112.

145. Mandell, R.B.; Koukuntla, R.; Mogler, L.J.; Carzoli, A.K.; Freiberg, A.N.; Holbrook, M.R.; Martin, B.K.; Staplin, W.R.; Vahanian, N.N.; Link, C.J.; Flick, R. A replication-incompetent rift valley fever vaccine: Chimeric virus-like particles protect mice and rats against lethal challenge. Virology 397, 187-198.

146. Lamere, M.W.; Lam, H.T.; Moquin, A.; Haynes, L.; Lund, F.E.; Randall, T.D.; Kaminski, D.A. Contributions of antinucleoprotein igg to heterosubtypic immunity against influenza virus. J. Immunol. 186, 4331-4339.

147. Virelizier, J.L.; Allison, A.C.; Oxford, J.S.; Schild, G.C. Early presence of ribonucleoprotein antigen on surface of influenza virus-infected cells. Nature 1977, 266, 52-54.

148. Yewdell, J.W.; Frank, E.; Gerhard, W. Expression of influenza a virus internal antigens on the surface of infected p815 cells. J. Immunol. 1981, 126, 1814-1819.

149. Eddy, G.A.; Peters, C.J.; Meadors, G.; Cole Jr, F.E. Rift valley fever vaccine for humans. Contr. Epidem. Biostatist. 1981, 3, 124-141.

150. Brown, J.L.; Dominik, J.W.; Morrissey, R.L. Respiratory infectivity of a recently isolated egyptian strain of rift valley fever virus. Infect. Immun. 1981, 33, 848-853.

151. Anderson, A.O.; Snyder, L.F.; Pitt, M.L.; Wood, O.L. Mucosal priming alters pathogenesis of rift valley fever. Adv. Exp. Med. Biol. 1988, 237, 717-723.

152. Gerrard, S.R.; Rollin, P.E.; Nichol, S.T. Bidirectional infection and release of rift valley fever virus in polarized epithelial cells. Virology 2002, 301, 226-235.

153. Anderson, G.W., Jr.; Slayter, M.V.; Hall, W.; Peters, C.J. Pathogenesis of a phleboviral infection (punta toro virus) in golden syrian hamsters. Arch. Virol. 1990, 114, 203-212.

154 Fisher, A.F.; Tesh, R.B.; Tonry, J.; Guzman, H.; Liu, D.; Xiao, S.Y. Induction of severe disease in hamsters by two sandfly fever group viruses, Punta Toro and Gabek Forest (Phlebovirus, Bunyaviridae), similar to that caused by Rift Valley fever virus. Am. J. Trop. Med. Hyg. 2003, 69, 269-276. 
155. Pifat, D.Y.; Smith, J.F. Punta Toro virus infection of C57BL/6J mice: A model for phlebovirusinduced disease. Microb. Pathog. 1987, 3, 409-422.

156. Chen, S.Y.; Matsuoka, Y.; Compans, R.W. Assembly and polarized release of Punta Toro virus and effects of brefeldin A. J. Virol. 1991, 65, 1427-1439.

157. Anderson, G.W., Jr.; Smith, J.F. Immunoelectron microscopy of Rift Valley fever viral morphogenesis in primary rat hepatocytes. Virology 1987, 161, 91-100.

158. Rosebrock, J.A.; Schellekens, H.; Peters, C.J. The effects of aging in vitro and interferon on the resistance of rat macrophages to Rift Valley fever virus (RVFV). Anat. Rec. 1983, 205, A165-A166.

159. do Valle, T.Z.; Billecocq, A.; Guillemot, L.; Alberts, R.; Gommet, C.; Geffers, R.; Calabrese, K.; Schughart, K.; Bouloy, M.; Montagutelli, X.; Panthier, J.J. A new mouse model reveals a critical role for host innate immunity in resistance to Rift Valley fever. J. Immunol. 2010, 185, 6146-6156.

160. Latham, P.S.; Sepelak, S.B.; Pifat, D.Y.; Smith, J.F. Role of hepatocytes and Kupffer cells in agedependent murine hepatitis caused by a phlebovirus, Punta Toro. J. Med. Virol. 1991, 33, 10-18.

161. Latham, P.S.; Sepelak, S.B. Effect of macrophage source and activation on susceptibility in an age-dependent model of murine hepatitis caused by a phlebovirus, Punta Toro. Arch. Virol. 1992, $122,175-185$.

162. Gowen, B.B.; Hoopes, J.D.; Wong, M.H.; Jung, K.H.; Isakson, K.C.; Alexopoulou, L.; Flavell, R.A.; Sidwell, R.W. TLR3 deletion limits mortality and disease severity due to Phlebovirus infection. J. Immunol. 2006, 177, 6301-6307.

163. Wang, T.; Town, T.; Alexopoulou, L.; Anderson, J.F.; Fikrig, E.; Flavell, R.A. Toll-like receptor 3 mediates West Nile virus entry into the brain causing lethal encephalitis. Nat. Med. 2004, 10, 1366-1373.

164. Najjar, I.; Fagard, R. STAT1 and pathogens, not a friendly relationship. Biochimie 2010, 92, 425-444.

165. Mendenhall, M.; Wong, M.H.; Skirpstunas, R.; Morrey, J.D.; Gowen, B.B. Punta Toro virus (Bunyaviridae, Phlebovirus) infection in mice: strain differences in pathogenesis and host interferon response. Virology 2009, 395, 143-151.

(C) 2011 by the authors; licensee MDPI, Basel, Switzerland. This article is an open access article distributed under the terms and conditions of the Creative Commons Attribution license (http://creativecommons.org/licenses/by/3.0/). 